\title{
THE THOMAS RECORDING GAS CALORIMETER
}

\author{
By R. S. Jessup
}

\section{ABSTRACT}

The Thomas recording gas calorimeter is described. Calculations are made showing the effects on the reading of the calorimeter of change in temperature and barometric pressure. Results of comparisons of the Thomas calorimeter with the Junkers calorimeter on Washington City gas and on commercial propane are given. The agreement of the results obtained with the two calorimeters is well within the accuracy claimed for the Thomas calorimeter. Measurements of the lag of the Thomas calorimeter are described.

\section{CONTENTS}

I. Introduction

II. Description of Thomas calorimeter

III. Standardization of calorimeter with hydrogen 104

IV. Effect of changes in temperature, barometric pressure, and atmospheric humidity

V. Comparisons with the Junkers calorimeter... 114

VI. Heating values outside the usual working range

VII. Lag of the Thomas calorimeter.

VIII. Previous work

IX. Acknowledgments

X. Conclusion

\section{INTRODUCTION}

The subject of gas calorimetry has been investigated in considerable detail at this bureau by Waidner and Mueller. ${ }^{1}$ These authors discuss the principles underlying the determinationof heating values of gases, and describe exhaustive tests of a number of commercial gas calorimeters. It was shown that several of the calorimeters tested could be used for measuring total heating values of gases to an accuracy of about 0.3 per cent. This accuracy can be attained, however, only at the expense of considerable time in making the necessary adjustments and observations, and in computing the results.

Since the above-mentioned work was done various types of recording gas calorimeters have come in to use, and numerous inquiries have been received by this bureau regarding the reliability of such instruments. One of these types, which is widely used at the present time, is known as the Thomas recording gas calorimeter, and the present paper describes the results of a critical study of this instrument and its behavior. A Thomas calorimeter, having a range of 0 to $700 \mathrm{Btu}$ per cubic foot, was loaned by the manufacturers for this investigation. 


\section{DESCRIPTION OF THE THOMAS CALORIMETER}

The Thomas calorimeter or any other recording calorimeter may be used as a secondary instrument, designed to be adjusted to indicate the heating value of the gas as determined with a standard instrument; for example, a water flow calorimeter of the ordinary type. If used in this way, the questions of interest concern the length of time the indications will remain correct, and whether the correctness will be affected by ordinary changes in temperature, barometric pressure, and atmospheric humidity.

The Thomas calorimeter was designed, however, not as a secondary instrument, but as a self-contained one, which could be standardized by the use of pure hydrogen. This self-contained feature necessarily leads to complications in design, and requires the operator to be familiar with the process of standardization, but provides some of the advantages inherent in a primary instrument. If a calorimeter has the characteristics demanded of a self-contained instrument, it will necessarily be equally or more satisfactory if used merely as a secondary instrument. In this investigation, therefore, the suitability of the Thomas calorimeter as a self-contained instrument was of major interest.

The principle upon which the Thomas calorimeter operates is as follows: Gas is burned at a constant rate and the heat developed is absorbed by a stream of air. The rates of flow of the gas, air for combustion, and the heat-absorbing air are regulated by metering devices, similar in construction to the ordinary wet gas meters. These metering devices are geared together and driven by an electric motor, so that the ratio of the rates of flow of gas and heat-absorbing air is constant. The products of combustion are kept separate from the heat-absorbing air, and are cooled very nearly to the initial temperature of the air. The water formed in the combustion is condensed to the liquid state. The rise in temperature of the heatabsorbing air is therefore proportional to the total heating value of the gas. This rise in temperature is measured by means of resistance thermometers of nickel, translated into Btu per cubic foot of gas under standard conditions, and recorded graphically.

The meters are mounted in a tank of water, within which is a smaller tank containing a reserve supply of water. A chain pump draws water from the reserve tank and delivers it into the main tank; the excess flows over a weir and returns to the reserve tank. Thus the water level in the main tank is automatically kept constant.

A schematic diagram of the calorimeter is shown in Figure 1, which was taken from the book of instructions for the care and operation of the calorimeter. Gas flows from the gas supply line through a pressure reducing orifice into a chamber from which part of it escapes through a bleeder burner. The area of the bleeder burner openings is sufficiently large so that the gas pressure in the chamber does not differ appreciably from that of the atmosphere. The remainder of the gas flows through the gas neter and connecting tubing to a mixing chamber where it is mixed with air from the combustion air meter. The mixture flows from the mixing chamber to the calorimeter burner. Figure 2 is an enlarged view of the burner unit.

The air from the combustion air meter is divided into two streams, one of which flows to the mixing chamber, while the other flows up 
around the outside of the burner tube and constitutes a supply of secondary air for combustion.

The burner is located in a chamber which is closed at the top and open at the bottom, so that the products of combustion rising from

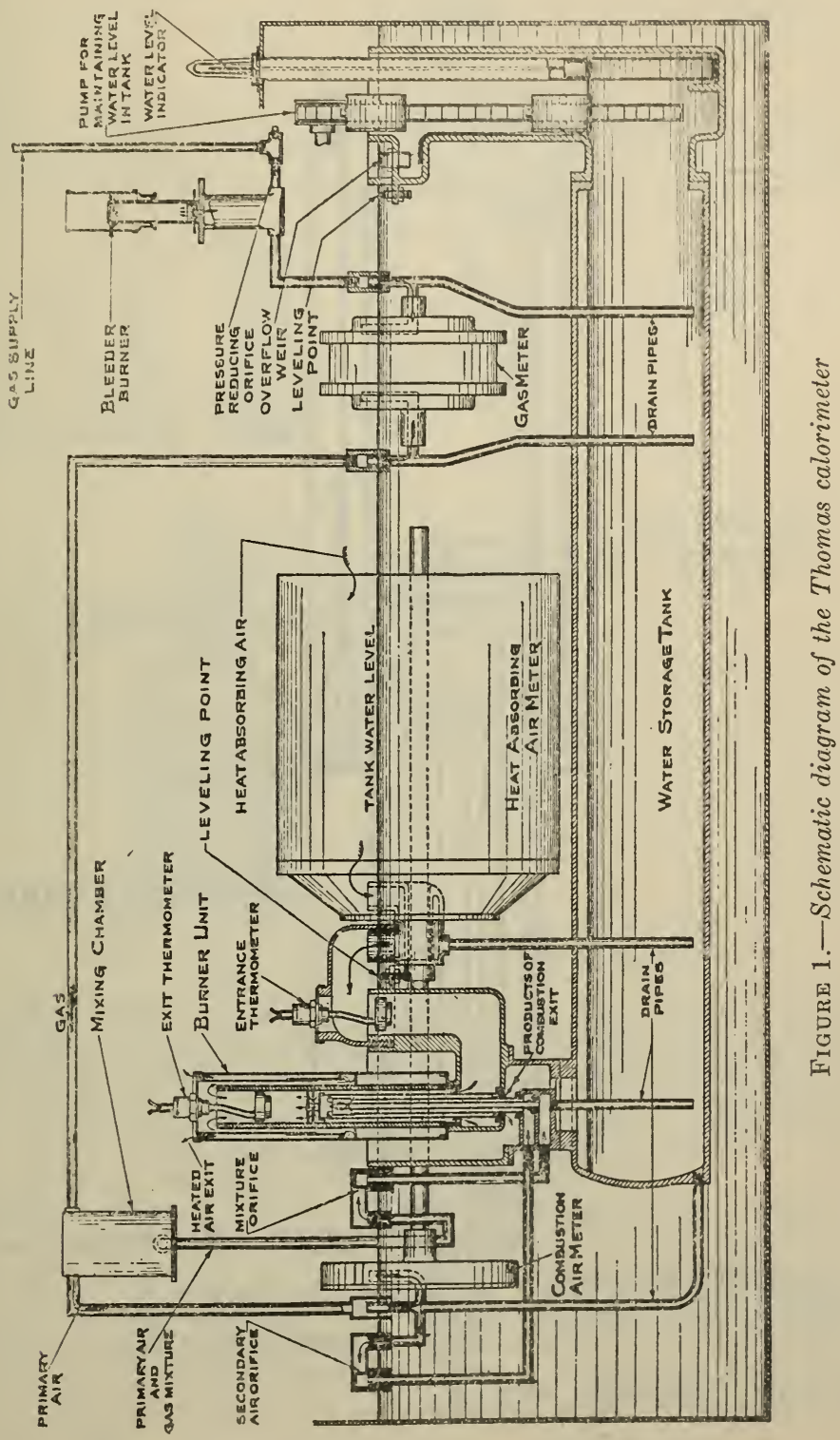

the burner are deflected and caused to flow downward. The heatabsorbing air flows upward past a system of fins which are attached to the outside of the burner chamber to promote heat transfer. The heat liberated in the combustion is nearly all absorbed by the heat- 
absorbing air, so that the products of combustion are cooled very nearly to the initial temperature of the air. The water formed in



FIGURE 2,-Diagram of burner unit and jacket

the combustion is condensed to the liquid state and drops into the water storage tank. 
The volume of the heat absorbing air is nearly a thousand times the volume of gas burned, ${ }^{2}$ so that the heat capacity of the heat absorbing air in relation to the amount of gas burned is comparable with the heat capacity of the water used to absorb heat in the ordinary water flow calorimeter. The temperature rise of the heat-absorbing air is measured by means of the entrance and exit thermometers shown in Figure 1. These are resistance thermometers made of nickel wire.

Figure 3, which was taken from the Thomas calorimeter instruction book, is a schematic diagram of the Leeds \& Northrup recording system, used with the calorimeter. The inlet thermometer, $T_{1}$, and

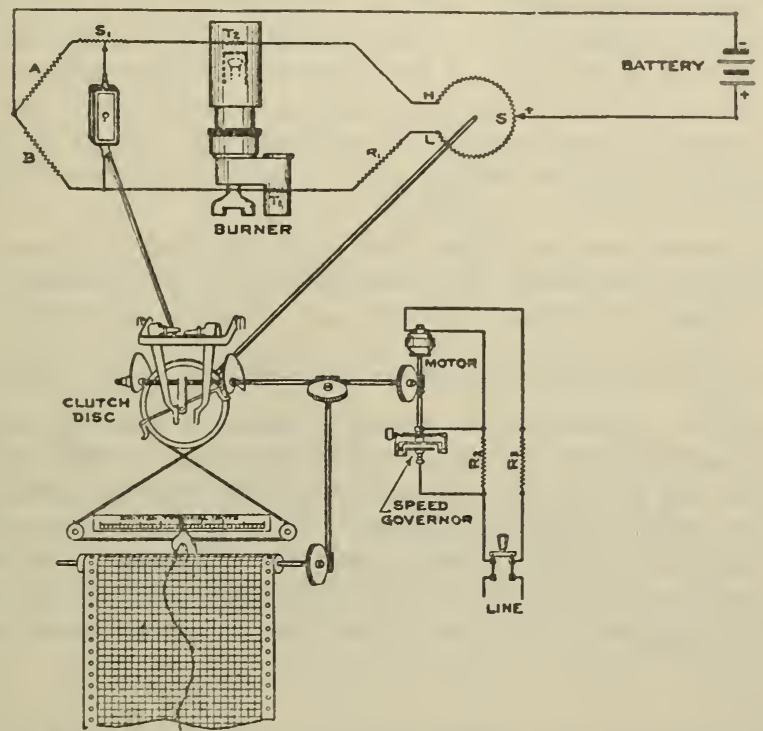

FIGURE 3.-Schematic diagram of recording system

outlet thermometer, $T_{2}$, are connected in adjacent arms of a Wheatstone bridge. Any lack of balance in the bridge causes the galvanometer needle to deflect and actuate the recording mechanism, which moves the sliding contact, $S$, so as to bring the bridge back into balance. The recording pen is simultaneously moved into a position corresponding to the new position of the contact, $S$.

The sliding contact, $S_{1}$, (fig. 3 ), is used to balance the bridge when heat-absorbing air is flowing through the system with the burner out and the recording pen set on the zero of the scale. This is called cold balancing the calorimeter, and its effect is to compensate for any small changes which may have occurred in the resistances or connecting wires of the thermometers. Current for the bridge is furnished by dry cells, or by a "trickle charger" connected to the A. C. power line.

2 The ratio of the volumes of heat absorbing air and gas is approximately $126.7 \times \frac{S}{100}$ to 1 , where $S$ is the full-scale reading. For the 0 to 700 range calorimeter the ratio is $126.7 \times 7$, or 887 to 1 . 
The ratio of the rates of flow of gas and heat-absorbing air may change with time due to unequal wear of the bearings, and to corrosion or deposits in the meters. To avoid errors due to this cause the gas meter is installed in such a way that it can be raised or lowered so as to vary the volume delivered by it per revolution. Gears are provided, by means of which the relative speeds of the gas meter and heat-absorbing air meter can be changed, so that when the gas meter is at the proper height, the two meters deliver at the same rate. The two meters can then be connected so that one delivers into, and the other pumps from a "prover bell" partially immersed in the water of the tank and suspended from one arm of a balance. The other arm of the balance is loaded with a counterweight so adjusted that the gas pressure in the bell does not differ appreciably from that of the atmosphere. The balance is provided with a pointer and scale to indicate the height of the prover bell. Any difference in the delivery rates of the two meters will cause the prover bell to rise or fall, and the height of the gas meter can be adjusted accordingly. 'This test is called the air-gas ratio test.

The adjustment made in this test is such that if the air and gas meters delivered the same volumes per revolution during operation as they do during the test, the volume of heat-absorbing air would be $126.73 \times \frac{S}{100}$ time: the volume of gas, where $S$ is the full-scale reading. In the test, however, the speed of the air meter is of the order of one two-hundredth of its usual operating speed, while the speed of the gas meter in the 0 to 700 range calorimeter is of the order of five times its usual opernting speed. It is not to be expected that over this range of speeds the ratio of the volumes delivered by the two meters will remain constant to 0.01 per cent, so that the ratio of heat absorbing air to gas for practical purposes may be given as $126.7 \times \frac{S}{100}$ to 1 .

To reduce heat loss the burner chamber is surrounded by a doublewalled, nickel-plated jacket, between the walls of which the heatabsorbing air flows after passing the outlet thermometer. The flow of air between the walls of the jacket is regulated by a baffle (shown in fig. 2) which can be adjusted. This baffle is adjusted by the manufacturers so that the calorimeter records the value 320.6 Btu per cubic foot under standard conditions ${ }^{3}$ for the heating value of pure hydrogen.

\section{STANDARDIZATION OF CALORIMETER WITH HYDROGEN}

When hydrogen is being burned in the 0 to 700 range calorimeter, the speed of the gas meter relative to that of the heat-absorbing air meter is increased in the ratio $21 / 11$, by appropriate changes in the gears in the gear train between the driving motor and the gas meter. The purpose of this is to bring the reading of the calorimeter when burning hydrogen into the usual operating range; that is, in the

\footnotetext{
The standard conditions are: $A$ temperature of $60^{\circ} \mathrm{F}$., the gas saturated with water vapor at that temperature, and a total pressure equivalent to that of a $30^{\circ}$-inch column of mercury at $32^{\circ} \mathrm{F}$., and under standard gravity.
} 
neighborhood of 600 on the scale. Under these conditions the calorimeter should read

$$
320.6 \times \frac{21}{11}=612
$$

The value $320.6 \mathrm{Btu}$ per cubic foot for the heating value of hydrogen is based on 68,635 calories 15 per mole for the heat of formation of water, which is the mean of values obtained by Berthelot and Matignon, ${ }^{4}$ Mixter, ${ }^{5}$ Thomsen, ${ }^{6}$ and Rumelin. ${ }^{7}$ Roth ${ }^{8}$ has critically reviewed the data of the observers mentioned above, and of Schuller and Wartha, ${ }^{\circ}$ and has selected 68,380 calories ${ }_{15}$ per molo at $18^{\circ} \mathrm{C}$. as the most probable value for the heat of formation of water. More recently Rossini ${ }^{10}$ has made a careful determination of the heat of formation of water, obtaining the value $68,313 \pm 10$ calories $_{15}$ per mole at $25^{\circ} \mathrm{C}$. These last two values, when reduced to the same temperature on the assumption that the heat of formation changes by -8 calories per mole per ${ }^{\circ} \mathrm{C}$., differ by less than 0.02 per cent.

The value used in adjusting the Thomas calorimeter is thus about 0.4 per cent higher than that deduced from the best available data. If uncompensated, this would cause the Thomas calorimeter to read high by 0.4 per cent when operating on illuminating gas. However, the calorimeter will indicate relatively too high a value for hydrogen and too low a value for ordinary illuminating gas, because of the fact that when burning hydrogen more water vapor will be condensed than is formed by combustion and less when burning illuminating gas. The amounts of water condensed relative to the amount formed depend upon two factors: (a) The difference in volume of the products of combustion and of the initial gas and air, and $(b)$ the difference in temperature of the products and of the initial gas and air.

The decrease in volume when combustion takes place tends to cause more water to be condensed than is formed in the combustion. This tendency is opposed by the excess in the temperature of the products over that of the initial gas and air. In order to calculate the effect of these two factors it was necessary to know the ratio of combustion air to gas, the contraction due to combustion, and the temperature of the products.

The delivery rates of the gas meter and combustion air meter were measured by connecting each of them in series with a calibrated 0.1 cubic foot wet meter and observing the time required for any convenient integral number of revolutions of the 0.1 cubic foot meter drum. The results obtained were as follows:

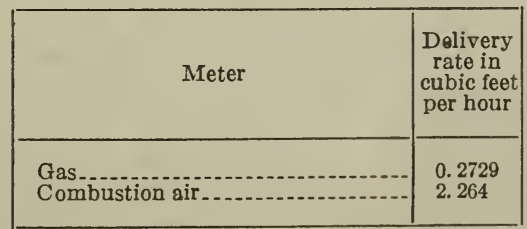

1 Ann. Chim. Phys. (6) vol. 30, p. 550, 1893.

8 Am. Jour. of Science, vol. 16, p. 214, 1903.

- Thermochemische Untersuchungen II, p. 45; Leipzig, 1885.

Zeits. für pìysik-Chem., vol. 58, p. 449, 1907.

8 Zeits. für Electrochemie, vol. 26, p. 288, 1920.

Ann. d. Phys. und Chemie, vol. 2, p. 359, 1877.

10 D. Jour. Research, vol. 6, p. 1, 1931. 
The ratio of combustion air to gas is therefore $\frac{2.264}{0.2729}=8.3$.

The contraction due to combustion of the illuminating gas used in this investigation was calculated from analyses of Washington city gas made by Branham. ${ }^{11}$ The calculated contraction was on the average 1.24 cubic feet per cubic foot of gas.

The temperature of the products of combustion was measured by means of a thermocouple, one junction of which was placed in the stream of products at the point where it leaves the burner chamber, and the other junction in the water of the tank. The temperature of the products of combustion was found to be $7^{\circ} \mathrm{F}$. higher than the temperature of the tank, both when illuminating gas was being burned in the calorimeter at the normal rate and when hydrogen was being: burned at 21/11 times the normal rate.

TABLE 1.-Difference between amounts of water 'formed and condensed when burning illuminating gas and effect on indicated heating value

\begin{tabular}{|c|c|c|c|c|c|c|c|c|c|}
\hline $\begin{array}{l}\text { Temperature } \\
\text { of tank }\end{array}$ & $\begin{array}{c}\text { Con- } \\
\text { traction } \\
\text { per } \\
\text { cubic } \\
\text { foot of } \\
\text { gas at } \\
t^{\circ} \mathrm{F} . \\
\text { and } 30 \\
\text { inches }\end{array}$ & $\begin{array}{c}\text { Density } \\
\text { of water } \\
\text { vapor at } \\
t^{\circ} \\
d\end{array}$ & $\begin{array}{c}\text { Water } \\
\text { con- } \\
\text { densed } \\
\text { per cubic } \\
\text { foot of } \\
\text { gas due to } \\
\text { contrac- } \\
\text { tion } \\
w\end{array}$ & $\begin{array}{c}\text { Density } \\
\text { of water } \\
\text { vapor at } \\
(t+7)^{\circ} \\
d^{\prime}\end{array}$ & $d^{\prime}-d$ & 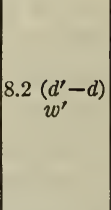 & $w-w^{\prime}$ & $L\left(w-w^{\prime}\right)$ & $\begin{array}{l}\text { Percent } \\
\text { of } 600 \\
\text { Btu }\end{array}$ \\
\hline $\begin{array}{c}{ }^{\circ} \mathrm{F} . \\
600 \\
80 \\
90\end{array}$ & \begin{tabular}{l|}
$F t .3$ \\
1.24 \\
1.24 \\
1.24 \\
1.24
\end{tabular} & $\begin{array}{c}\text { Lbs./ft. }{ }^{3} \\
0.000828 \\
.001151 \\
.001578 \\
.0 c 2134\end{array}$ & $\begin{array}{l}\text { Pound } \\
0.00103 \\
.00143 \\
.00196 \\
.00265\end{array}$ & $\begin{array}{c}\text { Lbs./ft. }{ }^{3} \\
0.001044 \\
.001437 \\
.001953 \\
.002616\end{array}$ & $\begin{array}{l}\text { Lb./ft. }{ }^{3} \\
0.000216 \\
.000286 \\
.000375 \\
.000482\end{array}$ & $\begin{array}{l}\text { Pound } \\
0.00177 \\
.00235 \\
.00308 \\
.00395\end{array}$ & $\begin{array}{c}\text { Pound } \\
-0.00074 \\
-.00092 \\
-.00112 \\
-.00130\end{array}$ & $\begin{array}{l}\text { Btu } \\
-0.78 \\
=.97 \\
=1.17 \\
-1.35\end{array}$ & $\begin{array}{l}-0.13 \\
=.16 \\
=.21 \\
-.24\end{array}$ \\
\hline
\end{tabular}

Using these data the combined effect of the two factors $(a)$ and $(b)$ was calculated. The results for illuminating gas are shown in Table 1. The first column gives the temperature of the tank and therefore the initial temperature of gas and combustion air. Column 2 gives the contraction per cubic foot of gas saturated with water vapor at the temperature of the tank. Column 3 gives the density of water vapor at the temperature of the tank. The values of density of water vapor were taken from Keenan's steam tables. Column 4 is the product of the corresponding figures in columns 2 and 3 , and represents the amount of water in excess of that formed in the combustion which would be condensed per cubic foot of gas burned if the products of combustion were cooled to the temperature of the tank. Column 5 gives the density of water vapor at the final temperature of the products of combustion. Column 6 gives the difference in the densities of water vapor at the temperature of the tank and at the temperature of the products of combustion; that is, the excess of the density of water vapor in the products of combustion over what it would be if the products were cooled to the temperature of the tank. Column 7 gives the increase in the quantity of water carried off by the products of combustion due to the fact that they were not cooled to the temperature of the tank. The factor 8.2 represents the volume of the products of combustion of 1 cubic foot of gas, and is the volume of gas (1.0) plus the volume of the combustion air (8.3), minus the contrac-

"A Am. Gas. J., vol. 135, No. 2, p. 42, August, 1931. 
tion (1.2), plus the increase in volume due to the higher temperature of the products (0.1). Column 8 gives the excess in the quantity of water condensed over that formed in the combustion, and column 9 gives the increased heat evolved due to this excess. Column 10 gives the percentage of increase in the heat evolved due to this excess condensation. It is seen that for this illuminating gas less water is condensed than is formed in the combustion, and that this results in from 0.13 to 0.24 per cent less heat being evolved than would be if all the water formed in the combustion were condensed.

The special test gears used when hydrogen is burnedin the 0 to 700 range calorimeter reduce the ratio of combustion-air to gas in the ratio $11 / 21$, so that with these gears this ratio becomes

$$
8.3 \times \frac{11}{21}=4.3
$$

Since the contraction when one cubic foot of hydrogen is burned is 1.5 the ratio of the volume of the products to volume of gas is $(1.0+4.3$ $-1.5)=3.8$.

Table 2 shows the calculations for hydrogen similar to those for illuminating gas in Table 1. It is seen that in this case more water is condensed than is formed in the combustion, resulting in an increase in the heat evolved amounting to from 0.14 to 0.47 per cent.

TABLE 2.-Difference between amounts of water vapor formed and condensed when burning hydrogen and effect on indicated heating value

\begin{tabular}{|c|c|c|c|c|c|c|c|c|c|}
\hline $\begin{array}{c}\text { Temperature } \\
\text { of tank } \\
t\end{array}$ & $\begin{array}{l}\text { Con- } \\
\text { trac- } \\
\text { tion } \\
\text { per } \\
\text { cubic } \\
\text { foot of } \\
\text { gas at } \\
t^{\circ} \mathrm{F} \text {. } \\
\text { and } 30 \\
\text { inches }\end{array}$ & $\begin{array}{c}\text { Density } \\
\text { of water } \\
\text { vapor at } \\
t^{\circ} \\
d\end{array}$ & $\begin{array}{c}\text { Water } \\
\text { con- } \\
\text { densed } \\
\text { per cubic } \\
\text { foot of } \\
\text { gas due } \\
\text { to con- } \\
\text { traction } \\
w\end{array}$ & $\begin{array}{c}\text { Density } \\
\text { of water } \\
\text { vapor at } \\
(t+7)^{\circ} \\
d^{\prime}\end{array}$ & $d^{\prime}-d$ & $\begin{array}{c}3.8\left(d^{\prime}-d\right) \\
w^{\prime}\end{array}$ & $w-w^{\prime}$ & $L\left(w-w^{\prime}\right)$ & $\begin{array}{c}\text { Per } \\
\text { cent of } \\
319 \\
\text { Btu }\end{array}$ \\
\hline $\begin{array}{l}{ }^{\circ} \mathrm{F} . \\
600 \\
80 \\
80\end{array}$ & $\begin{array}{l}\text { Ft. }{ }^{3} \\
1.50 \\
1.50 \\
1.50 \\
1.50\end{array}$ & $\begin{array}{l}\text { Lbs./ft. }{ }^{3} \\
0.000828 \\
.001151 \\
.001578 \\
.002134\end{array}$ & $\begin{array}{c}\text { Pounds } \\
0.00124 \\
.00173 \\
.00237 \\
.00320\end{array}$ & $\begin{array}{l}\text { Lbs./ft. }{ }^{3} \\
0.001044 \\
.001437 \\
.001953 \\
.002616\end{array}$ & $\begin{array}{l}\text { Lbs./ft. }{ }^{3} \\
0.000216 \\
.000286 \\
.000375 \\
.000482\end{array}$ & $\begin{array}{r}\text { Pounds } \\
0.00082 \\
.00109 \\
.00143 \\
.00183\end{array}$ & $\begin{array}{r}\text { Pounds } \\
0.00042 \\
.00064 \\
.00094 \\
.00137\end{array}$ & $\begin{array}{c}B t u \\
0.44 \\
.67 \\
.94 \\
1.43\end{array}$ & $\begin{array}{r}+0.14 \\
.22 \\
.31 \\
.47\end{array}$ \\
\hline
\end{tabular}

These calculations indicate that if the Thomas calorimeter were adjusted to give the correct total heating value for hydrogen (319.4 Btu per cubic foot) then when burning illuminating gas at any given temperature it would read low by an amount depending on the temperature of the tank during the hydrogen test. For example, if the hydrogen test were made with the tank temperature $65^{\circ} \mathrm{F}$., then when burning illuminating gas the calorimeter would read low by 0.3 per cent with the tank temperature at $60^{\circ} \mathrm{F}$., and by 0.4 per cent with the tank temperature at $90^{\circ} \mathrm{F}$. On the other hand, if the Thomas calorimeter is adjusted so as to read 0.4 per cent high when burning hydrogen with the tank temperature at $65^{\circ} \mathrm{F}$., then it would not be in error by more than 0.1 per cent due to condensation or evaporation of water at any temperature between $60^{\circ}$ and $90^{\circ} \mathrm{F}$.

It would appear from the foregoing considerations that, in standardizing the Thomas calorimeter with hydrogen, it would be better to use 320.6 Btu per cubic foot for the heating value of hydrogen rather 
than Rossini's value (319.4), which is almost certainly more nearly correct. This conclusion, however, is not supported by the experimental data obtained in comparing the Thomas and Junkers calorimeters. These data will be discussed more in detail later.

\section{THE EFFECTS OF CHANGES OF TEMPERATURE, BARO- METRIC PRESSURE, AND ATMOSPHERIC HUMIDITY}

The calorimeter is designed to give the total heating value of gas in Btu per cubic foot, the gas being saturated with water vapor at $60^{\circ} \mathrm{F}$. and under a total pressure equivalent to that of a 30 -inch column of mercury at $32^{\circ} \mathrm{F}$. and under standard gravity. In the actual operation of the calorimeter the gas is metered at the temperature of the tank and is saturated with water vapor at that temperature. If the temperature of the tank is higher than $60^{\circ} \mathrm{F}$. the density of the gas will be less than if the temperature were $60^{\circ} \mathrm{F}$., due partly to its thermal expansion and partly to the increase in vapor pressure of water which results in lower partial pressure of gas. The thermal expansion alone would not cause any appreciable error in the indications of the calorimeter, since the expansion of the heat absorbing air is practically the same as that of the gas. The effect of the higher vapor pressure of water at the higher temperature, however, is to decrease the amount of combustible material per unit volume of gas, and to increase the heat capacity per unit volume of the heat absorbing air. Both of these factors cause a decrease in the temperature rise of the heat absorbing air. This effect is approximately compensated for over the tank temperature range $60^{\circ}$ to $90^{\circ} \mathrm{F}$. by the change with temperature of the slope of the resistance-temperature curve of the thermometers. This may be seen from the following considerations.

When gas of a constant composition is being burned in the calorimeter the temperature rise of the heat-absorbing air is given by the relation

$$
\Delta t=k\left[\frac{D_{\iota}\left(1-\frac{p}{B}\right)}{C_{a} D_{a}\left(1-\frac{p}{B}\right)+C_{w} D_{\imath}}+e\right]
$$

where the symbols are defined as follows:

$\Delta t=$ temperature rise of the heat absorbing air.

$D_{0}=$ density of the dry gas at the temperature of the tank and under the existing barometric pressure. (Since the composition of the gas is constant $D_{\vartheta}$ depends only on temperature and pressure.)

$D_{a}=$ density of dry air under the same conditions.

$D_{w}=$ density of water vapor under saturation conditions at the temperature of the tank.

$C_{a}=$ heat capacity of unit mass of air.

$C_{x b}=$ heat capacity of unit mass of water vapor.

$B=$ barometric pressure.

$p=$ vapor pressure of water at the temperature of the tank.

$e=a$ term arising from the excess of water condensed over that formed by combustion.

$k=a$ constant whose magnitude depends on the units used for the other quantities, and on the air-gas ratio. 

by

The difference in resistance of the two thermometers will be given

$$
\Delta R=\frac{\Delta t \Delta R}{\Delta t}=k\left[\frac{D_{0}\left(1-\frac{p}{B}\right)}{C_{a} D_{a}\left(1-\frac{p}{B}\right)+C_{w} D_{w}}+e\right] \frac{\Delta R}{\Delta t}
$$

where $\frac{\Delta R}{\Delta t}$ is the average change in resistance of the thermometers per degree between the initial and final temperatures of the heatabsorbing air. Since the total resistance of the slide wire (S, fig. 3) remains constant, the term

$$
\left[\frac{D_{o}\left(1-\frac{p}{B}\right)}{C_{a} D_{a}\left(1-\frac{p}{B}\right)+C_{w} D_{w}}+e\right] \frac{\Delta R}{\Delta t}
$$

must be a constant independent of the tank temperature if the calorimeter reading is to be independent of tank temperature.

The resistance-temperature relation of the outlet thermometer was determined by measuring its resistance when irnmersed in a stirred kerosene bath whose temperature was measured by a platinumresistance thermometer. It was found that over the temperature range $60^{\circ}$ to $135^{\circ} \mathrm{F}$. the resistance of the thermometer could be expressed as a function of temperature by means of the quadratic equation.

$$
R_{t}-R_{60}=0.12520(t-60)+0.00008562(t-60)^{2}
$$

Observed values of resistance obtained in two series of measurements

\begin{tabular}{|c|c|c|c|c|}
\hline \multirow{2}{*}{$\begin{array}{c}\text { Tem- } \\
\text { perature }\end{array}$} & \multicolumn{4}{|c|}{$R_{t}-R_{80}$} \\
\hline & \multicolumn{3}{|c|}{ Observerl } & $\begin{array}{l}\text { Calcu- } \\
\text { later }\end{array}$ \\
\hline $\begin{array}{r}{ }^{\circ} F_{p} \\
p_{0}, 0 \\
75 \\
90 \\
105 \\
120 \\
135\end{array}$ & $\begin{array}{c}\text { First } \\
\text { series } \\
\text { ohms } \\
0.000 \\
1.8890 \\
3.835 \\
5.807 \\
7.821 \\
9.873\end{array}$ & $\begin{array}{l}\text { Second } \\
\text { seriess } \\
\text { ohms } \\
0.000 \\
1.89 \beta_{6} \\
3.833 \\
5.805 \\
7.820 \\
9.871 .\end{array}$ & $\begin{array}{l}\text { Mern } \\
\text { ohms } \\
0.000 \\
1.892 \\
3.834 \\
5.506 \\
7.8208 \\
9.872\end{array}$ & $\begin{array}{l}\text { Ohms } \\
0.000 \\
1.897 \\
3.833 \\
5.807 \\
7.820 \\
2.872\end{array}$ \\
\hline
\end{tabular}
are compared in Table 3 with values computed from this equation.

TABLE 3.-Resistance of outlet thermometer at various temperatures

Calculated values of the difference in resistance of the inlet and outlet thermometers when the calorimeter is burning a gas having a heating value equal to $700 \mathrm{Btu}$ per cubic foot under standard conditions are given in Table 4. The values used for the specific heat of 
water vapor and air in calculating this table are 0.460 and 0.2401 Btu per pound per ${ }^{\circ} \mathrm{F}$., respectively. Data on the density of air were taken from Bureau of Standards Circular No. 19, entitled "Standard Density and Volumetric Tables." Data on the properties of water vapor were taken from Keenan's steam tables. The relative densities of the gas were calculated on the assumption that the thermal expansion of gas is the same as that of air. The values of $e$ given in Table 4 are the products of the values of

$$
\frac{D_{o}\left(1-\frac{p}{30}\right)}{C_{a} D_{a}\left(1-\frac{p}{30}\right)+C_{w} D_{w}}
$$

in the preceding column and the figures given in the last column of Table 1 . The values of the temperature rise of the heat-absorbing air given in the next to the last column of Table 4 were calculated from the corresponding values of

$$
\left[\frac{D_{o}\left(1-\frac{p}{30}\right)}{C_{a} D_{a}\left(1-\frac{p}{30}\right)+C_{w} D_{w}}+e\right]
$$

on the assumption that the temperature rise of the heat-absorbing air is $42.45^{\circ}$ when the tank temperature is $60^{\circ} \mathrm{F}$. The values of $\Delta R$ in the last column were calculated from the corresponding values of $\Delta t$ with the aid of the resistance-temperature relation given above. The maximum difference between any two values of $\Delta R$ in Table 4 is seen to be 0.4 per cent.

$\mathrm{T}_{\mathrm{ABLE}}$ 4.-Calculated difference in resistance of inlet and outlet thermometers for

\begin{tabular}{|c|c|c|c|c|c|c|c|c|}
\hline Temperature of tank $t$ & $\begin{array}{l}\text { Vapor } \\
\text { pressure of } \\
\text { water } p\end{array}$ & $\begin{array}{l}\text { Density } \\
\text { of water } \\
\text { vapor }\end{array}$ & $\begin{array}{l}\text { Density of } \\
\text { dry air }\end{array}$ & $\begin{array}{l}C_{a} D_{a} \times \\
\left(1-\frac{p}{30}\right)\end{array}$ & \multicolumn{2}{|c|}{$C_{w} D_{w}$} & \multicolumn{2}{|c|}{$\begin{array}{l}C_{a} D_{a} X \\
\left(1-\frac{p}{30}\right)+ \\
C_{\omega} D_{\omega}\end{array}$} \\
\hline $\begin{array}{c}{ }^{\circ} F . \\
60 \\
70 \\
80\end{array}$ &  & $\begin{array}{l}\text { Lbs./ft. }{ }^{8} \\
0.000828 \\
.001151 \\
.001578 \\
.002134\end{array}$ & $\begin{array}{c}L b s . / f t .{ }^{3} \\
0.07656 \\
.07511 \\
.07372 \\
.07238\end{array}$ & $\begin{array}{r}\text { Btu/ft. } .^{\circ} \mathrm{F} . \\
0.018062 \\
.017590 \\
.017091 \\
.016555\end{array}$ & \multicolumn{2}{|c|}{$\begin{array}{r}B t u / f t . .^{\circ} \mathrm{F} \\
0.000381 \\
.000529 \\
.000726 \\
.000982\end{array}$} & \multicolumn{2}{|c|}{$\begin{array}{r}\text { Btu/ft. } .^{\circ} \mathrm{F} \\
0.018443 \\
.018119 \\
.017816 \\
.017537\end{array}$} \\
\hline Temperature of tank $t$ & $\begin{array}{c}\text { Density } \\
\text { of dry } \\
\text { gas } D_{0}\end{array}$ & . $\left(1-\frac{p}{30}\right)$ & $C_{a} D_{a}\left(1-\frac{p}{30}\right.$ & $+C_{\omega} D_{\omega}$ & $e$ & \multicolumn{2}{|c|}{$\Delta t^{\prime \prime}$} & $\Delta R$ \\
\hline $\begin{array}{l}{ }^{\circ} F \\
60 \\
70 \\
80 \\
90\end{array}$ & $\begin{array}{r}\text { (Relative) } \\
1.0000 \\
.9811 \\
.9629 \\
.9454\end{array}$ & $\begin{array}{r}0.9826 \\
.9569 \\
.9298 \\
.9006\end{array}$ & & $\begin{array}{l}53.27 \\
52.81 \\
52.19 \\
51.35\end{array}$ & $\begin{array}{r}-0.07 \\
-.08 \\
-.11 \\
-.12\end{array}$ & & $\begin{array}{l}5 \\
45 \\
07 \\
56 \\
88\end{array}$ & $\begin{array}{c}\text { Ohms } \\
5.469 \\
5.491 \\
5.494 \\
5.471\end{array}$ \\
\hline
\end{tabular}
gas having a heating value of 700 B. $t$. $u$. per cubic foot 
If the calorimeter reads correctly at full scale with the tank at any given temperature, and if the reading were proportional to the difference in resistance of the two thermometers then the calorimeter would read too low at points between zero and full scale due to the fact that the resistance temperature relation of the thermometers is not linear. The smooth curve in Figure 4 illustrates the relation which should exist between resistance and reading if the reading is to be proportional to temperature rise of the heat absorbing air rather than to difference in resistance of the two thermometers. The actual

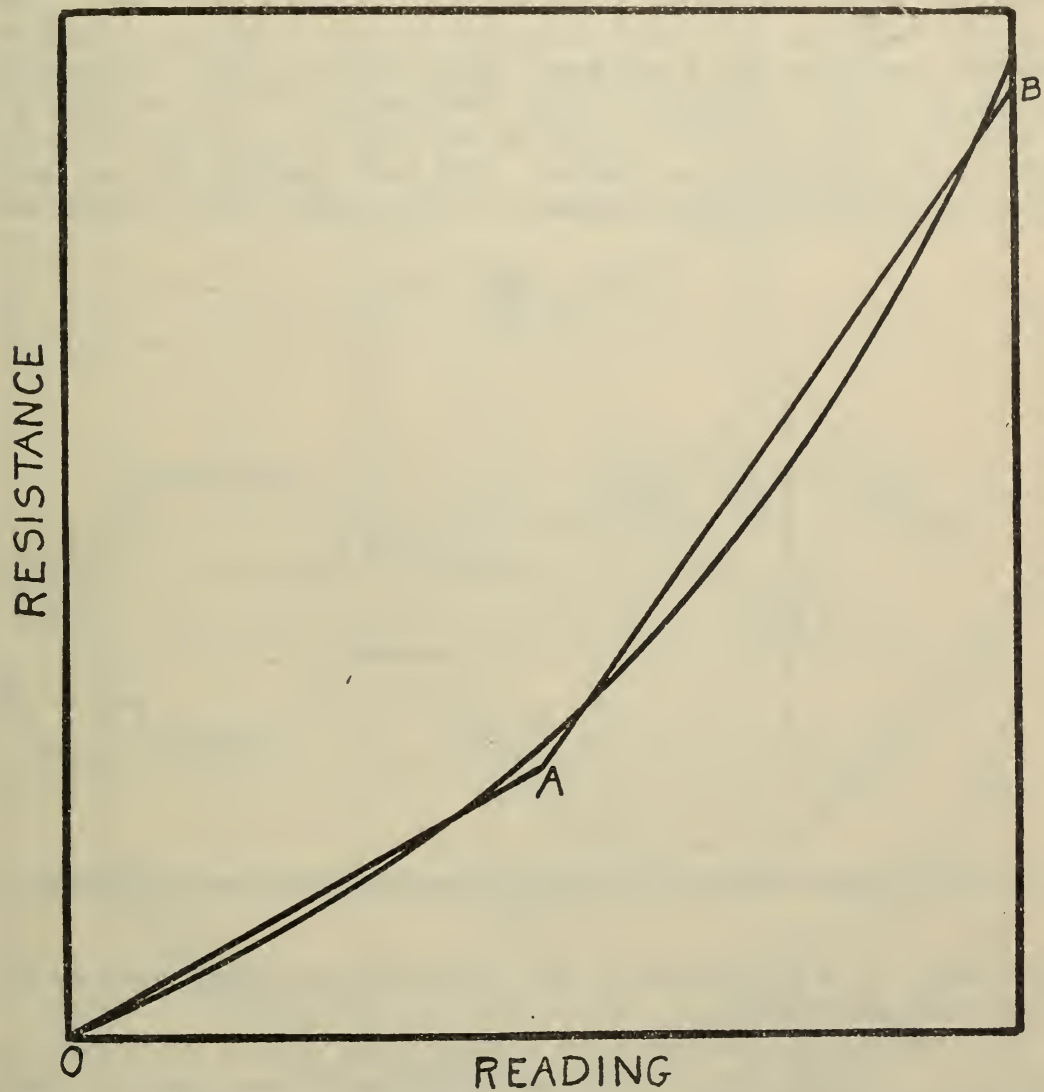

FIgURE 4.-Illustrating theoretical relation between difference in resistance of thermometers and reading of calorimeter (smooth curve), and actual relation (straight lines $O A$ and $A B$ )

resistance-reading curve is made to approximate the ideal relation illustrated by the smooth curve, by spacing the scale divisions closer together in the range from zero to half scale than in the range half to full scale. This gives a resistance-reading relation illustrated by the two straight lines, $O A$ and $A B$ (fig. 4).

To obtain the actual resistance-reading curve $(O A, A B$, fig. 4$)$ the two thermometers ( $T_{1}$ and $T_{2}$, fig. 3 ) were disconnected, and the resistance $R_{1}$ and slide wire were connected to a Wheatstone bridge with the battery lead connected to the sliding contact, $S$, as shown 148938-33-8 
in Figure 5. The recording pen was then set at various points on the recorder scale and the corresponding readings of the bridge were observed. These measurements were checked by a second method, suggested by representatives of the manufacturers. The inlet and outlet thermometers were disconnected, the inlet thermometer was replaced by a fixed resistance of about $50 \mathrm{ohms}$ while the outlet thermometer was replaced by a resistance which could be varied by steps of $0.1 \mathrm{ohm}$ from 50 to $60 \mathrm{ohms}$. The connecting leads were so adjusted that the recorder bridge was balanced at the zero of the scale for some particular value of the variable resistance. The variable resistance was then increased by any convenient amount, and the recording pen was moved along the scale until the recorder bridge was again balanced, when the reading of the recorder was observed. This procedure could be repeated for as many values of the variable resistance as desired. By both methods it was found that the change in the resistance of the outlet thermometer cor-



FIGURE 5.-Bridge connections used in measuring actual resistance-reading relation

responding to a movement of the recording pen from zero to full scale was 5.476 ohms.

The results obtained by both methods are shown graphically in Figure 6, in which are plotted the deviations of the observed resistances from a straight line through the points $O$ and $B$ of Figure 4 . The circles and crosses in Figure 6 represent observations by the first and second methods, respectively. It is seen that there is no appreciable systematic difference between the two sets of observations. There is a slight systematic deviation of the observed points from the straight line $O A$ in the range from zero to half scale.

Figure 7 shows the deviations from a straight line througn the points $O$ and $B$ (fig. 4 ) of the actual resistance-reading curve $O A B$ and of calculated resistance-reading curves for tank temperatures of $60^{\circ}, 70^{\circ}, 80^{\circ}$, and $90^{\circ} \mathrm{F}$. Data for the calculated curves were deduced from the resistance-temperature equation for the thermometers on the assumption that the temperature rise of the heat-absorbing air for a gas having a heating value of $700 \mathrm{Btu}$ per cubic foot is that 
given in the next to the last column of Table 4 , and that temperature rise for a given tank temperature is proportional to heating value of the gas. The temperature rise given in Table 4 for a tank tempera-

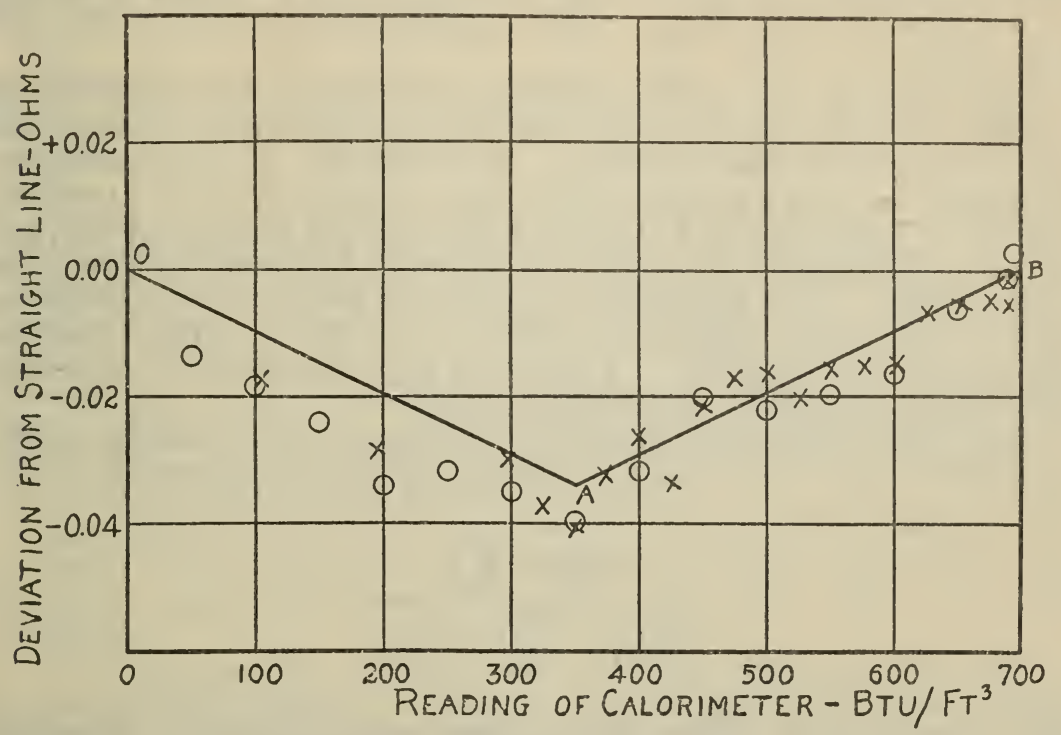

FIgURE 6.-Calibration curve of slide wire

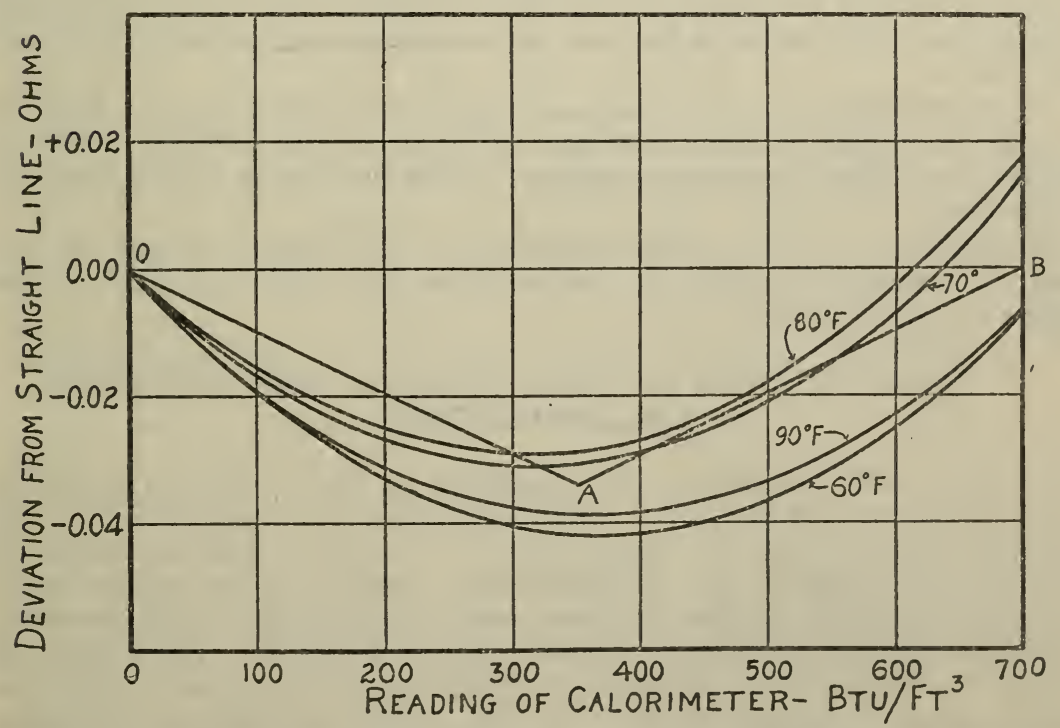

FIGURE 7.-Deviation from straight line of actual resistance-reading curve (straight lines $O A$ and $A B)$, and calculated curves for $60^{\circ}, 70^{\circ}, 80^{\circ}$, and $90^{\circ} \mathrm{F}$.

ture of $60^{\circ} \mathrm{F}$. was so chosen that the calculated curve for $66^{\circ}$ crosses the straight line $A B$ at $610 \mathrm{Btu}$. The calculated curves of Figure 7 therefore correspond to a calorimeter adjusted to read correctly at $610 \mathrm{Btu}$. when the tank temperature is $66^{\circ} \mathrm{F}$. A calorimeter so 
adjusted would read somewhat too high at tank temperatures between $66^{\circ}$ and about $85^{\circ} \mathrm{F}$. and somewhat too low at tank temperatures below $66^{\circ}$ and above $85^{\circ} \mathrm{F}$. The maximum difference between the straight line $A B$ and the calculated curves in the range from half to full scale is $0.018 \mathrm{ohms}$, which corresponds to about $2 \mathrm{Btu}$ per cubic foot.

The positions of the calculated curves relative to the actual curve, $O A$ and $A B$, will depend on the tank temperature at which the calorimeter is adjusted to read correctly. For example, if the calorimeter is adjusted to read correctly at 610 with the tank at $80^{\circ} \mathrm{F}$., then the calculated curve for $80^{\circ} \mathrm{F}$. will cross the straight line $A B$ at 610 , and the other calculated curves will be lowered at this point by about the same amount. The calorimeter would then read low at all temperatures except in the range from about $75^{\circ}$ to $80^{\circ} \mathrm{F}$. The condition represented by the curves of Figure 7 is approximately the condition which the manufacturers attempt to realize.

The effect of varying barometric pressure on the reading of the calorimeter may be obtained by differentiating the expression.

$$
\frac{D_{g}\left(1-\frac{p}{B}\right)}{C_{a} D_{a}\left(1-\frac{p}{B}\right)+C_{w} D_{w}}
$$

with respect to $B$. When this is done, and the proper numerical values substituted in the expression for the derivative, it is found that the change in reading for 1 inch change in barometric pressure is less than 0.01 per cent for any tank temperature between $60^{\circ}$ and $90^{\circ} \mathrm{F}$.

Representatives of the manufacturers have stated that it is their practice to adjust calorimeters to read as nearly as possible correctly at the prevailing barometric pressure of the locality in which they are to be used.

The effect of atmospheric humidity is eliminated because all gas and air passing through the calorimeter are saturated with water vapor in the meters.

\section{COMPARISONS OF THE THOMAS AND JUNKERS CALORIMETERS}

The Thomas calorimeter was installed in the chemistry building of this bureau late in 1926. The installation was inspected by U. O. Hutton, representing the manufacturers, who also ran an air-gas ratio test and a hydrogen test. The hydrogen used in this test and in most of the subsequent hydrogen tests was obtained from the low-temperature laboratory of this bureau and was 99.98 per cent pure. In one of the hydrogen tests hydrogen from this source was used alternately with hydrogen produced by the action of water on hydrone, an alloy of sodium and lead. No difference was observed in the reading of the calorimeter depending on which sample of hydrogen was being burned.

Numerous comparisons of the Thomas calorimeter with Junkers calorimeters were made in 1928, 1929, and 1931. The gas used in these comparisons was drawn from the Washington city gas mains, 
and was stored in a holder in order to obtain gas of constant composition for the tests. Before January, 1931, this gas was a carbureted water gas; after that time it was a carbureted water gas enriched with natural gas. The heating value of the gas varied from about 510 to $620 \mathrm{Btu}$ per cubic foot.

Two Junkers type calorimeters were used at different times. One of these was an original type Junkers (No. 1209) which had been investigated by Waidner and Mueller, ${ }^{12}$ and the other a HinmanJunkers (No. 724) which had been tested by comparison with No. 1209.

The Junkers calorimeters were operated in accordance with directions given in Bureau of Standards Circular No. 48, entitled "Standard Methods of Gas Testing." The 0.1 cubic foot meter used with the Junkers calorimeters was calibrated frequently by means of a 0.1 cubic foot bottle, following the procedure described in Circular 48 . Several sets of mercurial thermometers were used, all of which had been calibrated by the thermometry section of this bureau. The differential corrections for these thermometers were determined at frequent intervals during the investigation.

The Thomas calorimeter was operated in accordance with directions given in the instruction book furnished by the manufacturers. The periodic care recommended in this instruction book was given regularly.

The results of the comparisons with the Junkers calorimeter are summarized in Table 5. It is seen from this table that the two instruments nearly always agreed within 1 per cent, ${ }^{13}$ which is the accuracy guaranteed for the Thomas calorimeter by the manufacturers. In only 1 of the 43 comparisons listed in Table 5 did the difference exceed 1 per cent. On the average, the results obtained with the Thomas calorimeter were higher than those obtained with the Junkers calorimeter by $0.35 \mathrm{Btu}$. per cubic foot, or less than 0.1 per cent.

Hydrogen tests were made at various times during the investigation. It was found that the reading of the calorimeter depended somewhat on the current used in the bridge circuit of the recorder. Thus with the trickle charger ( 2.2 volts) the reading during the hydrogen tests was always 612 , while with dry cells ( 1.5 volts) the reading was always 610 . The reading was also $2 \mathrm{Btu}$. higher with the trickle charger than with dry cells when illuminating gas was being burned in the calorimeter. ${ }^{14}$

The results on illuminating gas given in Table 5 were obtained with dry cells furnishing the bridge current. They therefore correspond to a reading of 610 in the hydrogen test instead of the design value

12 See footnote 1 , p. 99.

13 In some of the preliminary measurements the Thomas calorimeter readings were systematically higher than the Junkers results by about 1.5 per cent. This difference was apparently due to not allowing sufficient time for the water in the 0.1 cubic foot meter used with the Junkers calorimeter to become thoroughly saturated with gas. The results obtained in investigating this point indicate that about 15 or 20 cubic feet of carbureted water gas must be passed through the meter at the rate of 5 cubic feet per hour to thoroughly saturate the water. With the present Washington city gas, which is carbureted water gas enriched with natural gas, the lowering in heating value due to fresh water in the meter was about 1 per cent. About 10 cubic feet of gas must be passed through the meter to saturate the water. This is not in accord with the results obtained by Waidner and Mueller (footnote 1, p. 99), who report that the effect, due to fresh water in the meter, on the observed heating value of a gas was of the order of 0.5 per cent and that the water was practically saturated, so far as calorimetric measurements were concerned, after the passage of 2 or 3 cublc feet of gas. Some results ob tained recently by members of the gas chemistry section of the bureau indicate that part of the difference originally observed between the Junkers and Thomas calorimeters may have been due to selective absorption of constituents of the gas by rubber tubing.

$14 \mathrm{~A}$ different type of rectifier is now furnished with the Thomas calorimeter. One of these new rectiflers has been installed recently in the calorimeter at this bureau, and it is found that the reading of the calorimeter is practically the same with the rectifler as with the dry cells. 
612. If the trickle charger had been used, or if the calorimeter had been adjusted so as to read 612 on the hydrogen test with dry cells, it seems probable that the readings on illuminating gas would have been higher by $2 \mathrm{Btu}$, or, on the average, 2.35 Btu higher than the results obtained with the Junkers calorimeter.

TABLE 5.-Comparisons of the Thomas and Junkers calorimeters on illuminating gas

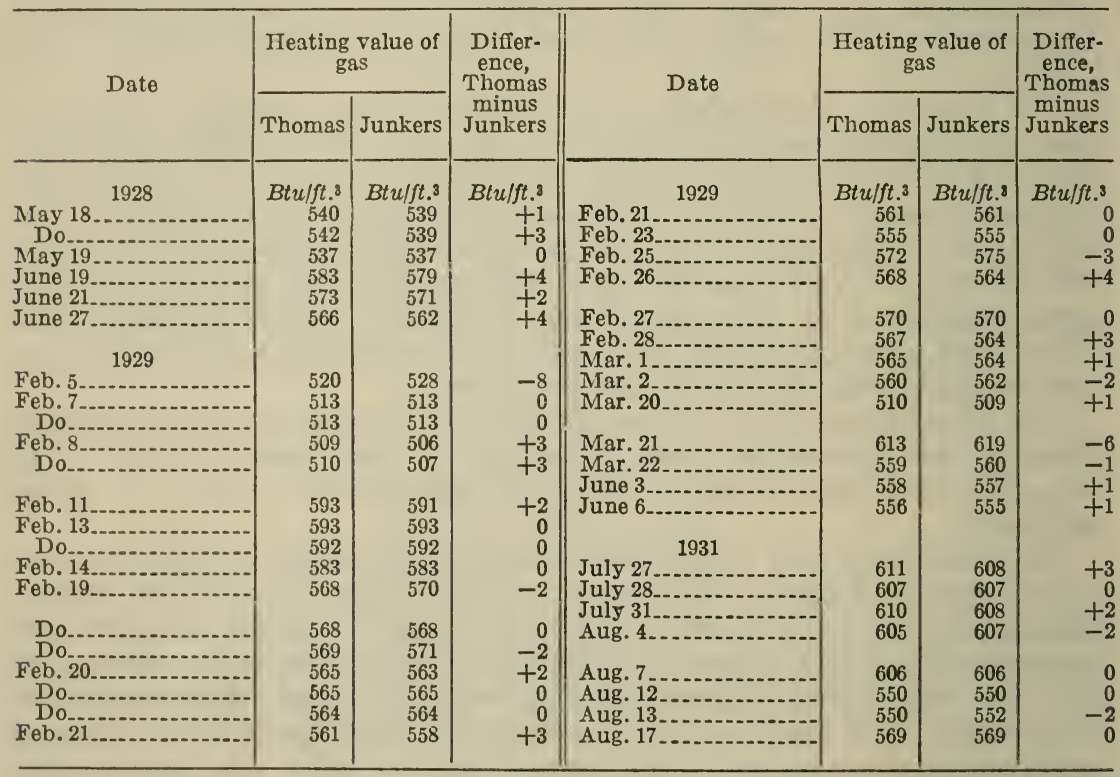

Thus the results of the calculations given in Section III of this paper, which indicate that it is better to use $320.6 \mathrm{Btu}$ per cubic foot for the heating value of hydrogen in standardizing the Thomas calorimeter, are not confirmed by the experimental results. The experimental results indicate that it is better to use $319.3 \mathrm{Btu}$ per cubic foot, which is practically identical with the value obtained by Rossini. The difference is about 0.4 per cent, which is well within the accuracy guaranteed for the Thomas calorimeter and not much greater than the uncertainty of the results obtained with the Junkers calorimeter.

Although the manufacturers guarantee an accurscy of only 1 per cent for the Thomas calorimeter they believe that if properly adjusted and given the periodic attention which they recommend, it will give results which are accurate within 0.4 per cent. The results obtained in comparisons with the Junkers calorimeter indicate that the Thomas calorimeter may be expected to give results which are at least precise within 0.4 per cent, since in only 12 of the 43 comparisons did the difference between the results obtained with the two calorimeters exceed that amount. These comparisons, however, indicate that if the Thomas calorimeter had been adjusted to read 612 instead of 610 in the hydrogen test, there would have been a systematic difference of 0.4 per cent between the Thomas and Junkers calorimeters. It is obviously impossible to decide from these comparisons whether the Thomas calorimeter, when adjusted to read 612 in the hydrogen test, 
gives results which are too high by 0.4 per cent on the average, or whether the Junkers calorimeter results are too low by the same amount, or whether part of the difference should be charged to each calorimeter. All that can be said is that the two instruments agreed within the combined experimental errors.

\section{HEATING VALUES OUTSIDE THE USUAL WORKING RANGE}

The data given in Table 5 were obtained on samples of gas having heating values ranging from about 510 to $620 \mathrm{Btu}$ per cubic foot. This is probably the usual working range of the Thomas calorimeter having the range 0 to $700 \mathrm{Btu}$ per cubic foot. It is of interest, however, to have data on the performance of the instrument over other parts of the range. Such data might have been obtained by comparisons with the Junkers calorimeter, using gases of various heating values. It was simpler, however, to use a gas of constant heating value and vary the speed of the gas meter. This could be done by changing some of the gears in the gear train between the driving motor and the gas meter. Table 6 shows data obtained in this way with hydrogen and illuminating gas.

TABLE 6.-Effect of changing speed of gas meter in the Thomas calorimeter

\begin{tabular}{|c|c|c|c|}
\hline Gas & $\begin{array}{c}\text { Relative } \\
\text { speed of } \\
\text { gas meter }\end{array}$ & $\begin{array}{l}\text { sen } \\
\text { Reading } \\
\text { of Thom } \\
\text { as calo- } \\
\text { rimeter }\end{array}$ & $\begin{array}{l}\text { Calculat- } \\
\text { ed read- } \\
\text { ing }\end{array}$ \\
\hline Hydrogen_.... & $\left\{\begin{array}{l}1_{33 / 44} \\
11 / 21\end{array}\right.$ & $\begin{array}{l}\begin{array}{l}612 \\
374 \\
321\end{array} \\
32\end{array}$ & $\begin{array}{l}374 \\
321\end{array}$ \\
\hline Illuminating gas. & $\begin{array}{l}2118 \\
1^{21 / 45}\end{array}$ & $\begin{array}{l}550 \\
321 \\
643 \\
256 \\
553\end{array}$ & $\begin{array}{l}322 \\
643 \\
257 \\
\end{array}$ \\
\hline
\end{tabular}

The figures in the column headed "calculated reading" were obtained from the average reading when the speed of the gas meter was 1 on the assumption that the reading should be proportional to speed. The agreement between the actual and calculated readings indicates that the calorimeter should give satisfactory results in the range covered, although the manufacturer's guaranty of 1 per cent accuracy holds only from half to full scale.

Thomas calorimeters having different ranges are practically identical with the one investigated here except that the delivery rates of the gas meters are different. The necessary changes were made in the 0 to 700 range instrument at this bureau to change the range to 0 to 3,000 , and two comparisons with the Junkers calorimeter were made on commercial propane. The net heating value of the gas was determined by means of the Junkers calorimeter, and the total heating value calculated from the net on the assumption that the gas was pure propane. The results obtained are shown in Table 7. The agreement is seen to be within about 0.3 per cent. 
TABLE 7.-Comparison of Thomas and Junkers calorimeters on propane

\begin{tabular}{|c|c|c|c|c|}
\hline Dute & Test No. & Thomas & Junkers & $\begin{array}{l}\text { Differ- } \\
\text { ence } \\
\text { Thomas- } \\
\text { Junkers }\end{array}$ \\
\hline Aug. 21, $1931 \ldots$ & $\begin{cases}1 \\
& 2\end{cases}$ & $\begin{array}{l}2,481 \\
2,481\end{array}$ & $\begin{array}{l}2,479 \\
2,473\end{array}$ & $\begin{array}{l}+2 \\
+8\end{array}$ \\
\hline
\end{tabular}

\section{LAG OF THE THOMAS CALORIMETER}

The comparisons of the Thomas and Junkers calorimeters described in the preceding section were made on gas drawn from holders, and therefore having approximately constant heating value. The comparisons were made after the calorimeters had been operating on this gas for a sufficiently long time so that the results were not affected by lag. When operating on gas whose heating value changes with time the reading of the calorimeters will lag behind the heating value of the gas. The lag of the Thomas calorimeter depends on four factors, namely, (a) the time required for gas to flow from the point at which it enters the calorimeter to the burner; $(b)$ the thermal lag; that is, the lag of the heated metal parts of burner and jacket and of the outlet thermometer; $(c)$ mechanical lag, that is, the lag of the recording mechanism; (d) lag due to change in the amounts of the various constituents of the gas which are dissolved in the water in the gas meter.

The magnitudes of $(b)$ and $(c)$ may be inferred from Figure 7 which is the record obtained during a hydrogen test. At $A$ and $B$ the recording pen was moved from its equilibrium position and then allowed to return. The time required is a measure of the mechanical lag, which is seen to be negligibly small, although in some cases the pen stops at about $1 \mathrm{Btu}$ from its equilibrium position and remains there for some time.

The combined effect of thermal and mechanical lag is illustrated in that part of the curve from $C$ to $D$ (fig. 7). When the burner was extinguished at $C$ the recording pen moved to the zero of the scale along the curve $C D$. Ninety per cent of the change had taken place in 4.2 minutes.

The combined effect of all of the lags was determined as follows: The calorimeter was connected through a 3-way stop-cock to the gas mains and to a holder containing gas which had been diluted with nitrogen. Gas could then be drawn either from the mains or from the holder. Figure $\mathrm{S}$ shows the record obtained when the calorimeter was switched from gas from the mains to gas from the holder. It was 4.5 minutes after switching to the holder gas before the first indication of a change in heating value was observed, and 6.5 minutes more before 90 per cent of the change had taken place. Practically the same results were obtained when the calorimeter was switched from the gas of lower heating value to that of higher heating value.

It is not possible from these observations to determine each of the factors $(a)$ and $(d)$ separately. For example, when the first change in heating value is observed after switching from one gas to another, it is probable that all of the original gas has not been swept out of the mixing chamber, and therefore the time required for all this original gas to be swept out is greater than 4.5 minutes. 
While the lag would cause an error in the values recorded by the calorimeter if the heating value of the test gas was changing, the effects of lag would tend to balance out in the average heating value calculated from records over considerable periods of time.

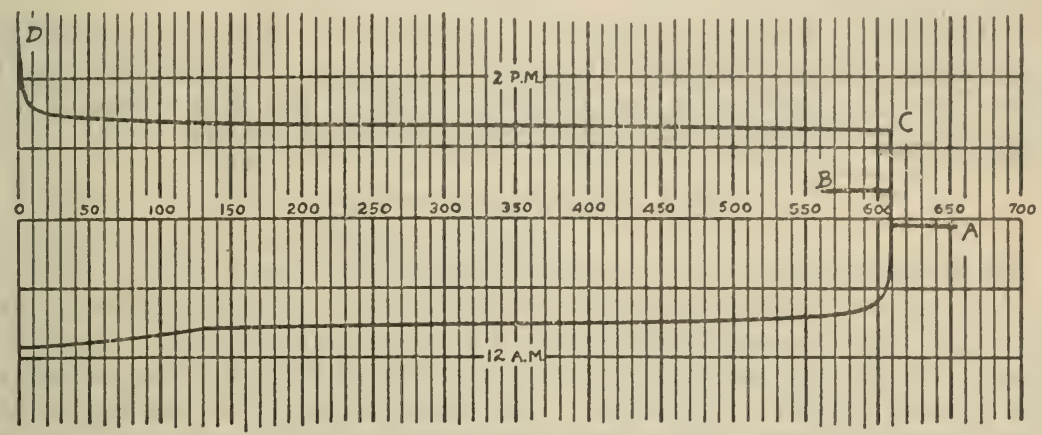

FIGURE 8.-Record made during a hydrogen test

The time required for gas to flow from the point at which it enters the calorimeter to the burner will be different for different range calorimeters on account of the different speeds of the gas meters. According to measurements made by the manufacturers the time interval

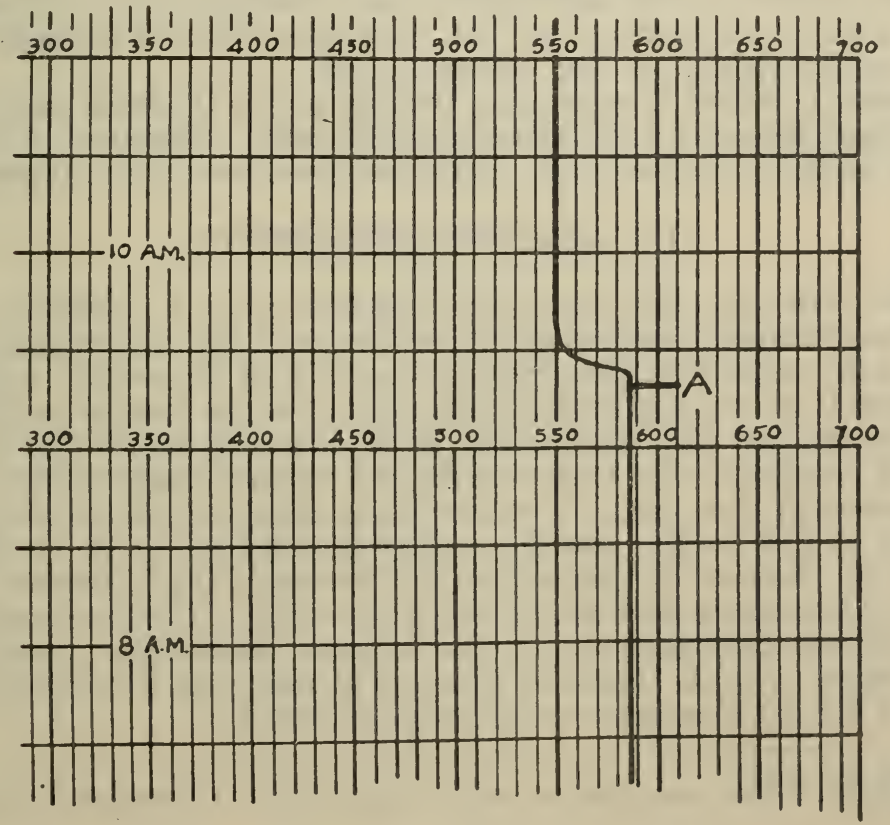

Figure 9.-Record made in determining the lag of the Thomas calorimeter

between turning off the gas and the first indication of a change in heating value of the gas varies from 1.5 minutes for the 0 to 150 range calorimeter to 8.5 minutes for the 0 to 2,100 range calorimeter. 
The thermal lag of the 0 to 150 range instrument is greater than that of any of the higher range instruments. This is due to the fact that it is necessary to preheat the gas in order to get it to burn satisfactorily, and the preheating device greatly increases the heat capacity of the burner.

Calorimeters having ranges of 0 to 1,800 or higher are provided with larger mixing chambers than lower range instruments in order to damp out fluctuntions in the delivery rates of the gas meters. The larger mixing chamber increases the lag to some extent.

\section{PREVIOUS WORK}

An investigation of the 'Thomas calorimeter was made in 1923 by R. A. Ragatz ${ }^{15}$ at the University of Wisconsin. He made 24 comparisons of a Thomas calorimeter with a Junkers calorimeter. In all but three of these comparisons the results obtained with the two calorimeters agreed within 1 per cent. His measurements of the lag of the 'Thomas calorimeter were in good agreement with those described here. He found, when the Thomas calorimeter was operating on gas of a constant heating value, that a sudden decrease in room temperature of $34^{\circ} \mathrm{F}$. caused a lowering of $4 \mathrm{Btu}$ per cubic foot in the reading.

A Thomas calorimeter, manufactured in England, and differing in some details from the one studied at this bureau, has been investigated by Blackie, Ockelford, Baker, and Hales. ${ }^{16}$

The accuracy of the instrument was investigated by comparing it with a Boys calorimeter, and the authors state that the agreement was usually within \pm 1 Btu per cubic foot.

Results obtained in measuring the lag of the Thomas calorimeter are in good agreement with those obtained here. The effect of changes in gas pressure, motor speed, and water level were also investigated.

\section{ACKNOWLEDGMENTS}

This work was done under the direction of E. F. Mueller, of the heat measurements section of this bureau, and the author is indebted to him for valuable advice during the course of the work. Acknowledgment is due to Cutler-Hammer (Inc.), for the loan of a Thomas calorimeter, and to U. O. Hutton, E. X. Schmidt, and T. M. Gilbert, of that company, who have contributed valuable suggestions during the course of the work. The work was done in the gas chemistry section of this bureau and the author is indebted to E. R. Weaver and J. H. Eiseman of that section for the use of the laboratory facilities and for advice and assistance in the work. The comparisons of the 'Thomas calorimeter with the Junkers calorimeter during 1929 were made by S. A. Guerrieri who was at that time a member of the staff of the gas chemistry section of the bureau.

16 Thesis, unnublished.

16 Department of Scientiflc and Industrial Research of Great Britain. Fuel Research Technical Paper No. 20, 1927. 


\section{CONCLUSION}

It may be concluded from the results obtained in this investigation that the Thomas calorimeter can be used to measure total heating values of gases with an accuracy well within 1 per cent, provided the calorimeter is given the necessary care, and provided the heating value of the gas does not vary rapidly. If the heating value of the gas varies with time the recorded readings of the calorimeter will be in error due to lag by an amount depending on the rapidity of the variation. The average reading over considerable periods of time will be unaffected by lag.

Wasuington, November 16, 1932. 